\title{
A neurological and biochemical study of early lead poisoning
}

\author{
JUDITH A S ASHBY
}

From the Department of Occupational Health, University of Manchester, Manchester M13 9PT, UK

ABSTRACT Changes in nerve conduction velocity were found in 94 workers exposed to lead in a battery factory compared with 94 age-matched controls. There was no clinical evidence of nerve damage in the lead workers. The mean blood lead concentration in the 94 lead workers was 2.9 $\mu \mathrm{mol} / \mathrm{l}(60 \mu \mathrm{g} / 100 \mathrm{ml})$ and their length of exposure to lead ranged from 6 months to 33 years.

All mean maximum motor nerve conduction velocities (MMCV) measured were highly statistically significantly lower in the lead-exposed group when compared with their age-matched controls. Thus mean ulnar MMCV was $53.4 \mathrm{~m} / \mathrm{s}$ in lead workers and $55.6 \mathrm{~m} / \mathrm{s}$ in control subjects $(\mathrm{p}<0.0005)$; mean median MMCV was $55.9 \mathrm{~m} / \mathrm{s}$ in lead workers and $57.3 \mathrm{~m} / \mathrm{s}$ in control subjects $(\mathrm{p}<0.01)$; mean radial MMCV was $63.9 \mathrm{~m} / \mathrm{s}$ in lead workers and $71.1 \mathrm{~m} / \mathrm{s}$ in control subjects $(\mathrm{p}<0.0005)$; mean peroneal MMCV was $46.1 \mathrm{~m} / \mathrm{s}$ in lead workers and $47.6 \mathrm{~m} / \mathrm{s}$ in control subjects $(\mathrm{p}<0.005)$.

The amplitude of the muscle action potential produced by proximal stimulation of a nerve was expressed as a percentage of the amplitude of the muscle action potential produced by distal stimulation and the percentage amplitude thus obtained used as an indicator of the conduction velocity of slower fibres (SFCV). Peroneal nerve percentage amplitude of lead workers was statistically significantly lower ( $p<0.005$ ) than in the control group (means $86.6 \%$ and $90.3 \%$ respectively). There were, however, no significant differences in the percentage amplitude in the ulnar and median nerves. It is suggested that percentage amplitude is an inappropriate indicator of SFCV in ulnar and median nerves.

There was no statistically significant correlation to indicate that progressive slowing of nerve conduction (MMCV and SFCV) was associated with increasing exposure to lead (as indicated by blood and urine lead concentrations) or with the commonly measured biochemical changes associated with disturbed haemopoiesis in lead exposure $(\delta$-aminolaevulinic acid dehydrase; free erythrocytc protoporphyrin; haemoglobin and urinary $\delta$-aminolaevulinic acid). MMCV of the ulnar nerve was the only conduction velocity statistically significantly correlated with length of exposure to lead. Increased length of exposure to lead was associated with a decrease in the ulnar MMCV.

Only 13 of the subjects had been exposed to lead for two years or less and in none of them had the blood lead ever risen above $3.9 \mu \mathrm{mol} / 1(80 \mu \mathrm{g} / 100 \mathrm{ml})$ in three-monthly tests (mean blood lead concentration at time of testing: $2.8 \mu \mathrm{mol} / \mathrm{l}$ ). In these subjects the MMCV of ulnar, radial, and peroneal nerves and the peroneal percentage amplitude were statistically significantly reduced. The results from this group suggest that the onset of nerve conduction changes occurs within two years and at concentrations of lead in blood of less than $3.9 \mu \mathrm{mol} / 1(80 \mu \mathrm{g} / 100 \mathrm{ml})$.

There is considerable inconsistency in the results obtained from electrophysiological studies of the lower motor neurone in workers exposed to lead. Thus several studies on lead workers without

Received 6 December 1978

Accepted 2 February 1979 neurological symptoms have shown some alteration in peripheral nerve conduction velocity. ${ }^{1-7}$ On the other hand, several investigations of leadexposed subjects exhibiting clinical evidence of neurological disturbance have failed to show any change in motor nerve conduction velocity, although the authors could not exclude damage to 
the anterior horn cell. ${ }^{8-11}$ This has been interpreted as indicating that the neurological manifestations of lead poisoning have their origin either in the upper motor neurone ${ }^{11}$ or the anterior horn cells that are the origin of the lower motor neurone. ${ }^{9}$

There are probably several reasons for this inconsistency. Firstly, choice of nerve: workers studying more than one nerve have found a gradation in effect. Though the findings are inconsistent the tendency appears to be for the peroneal nerve to be one of the least sensitive indicators of lead neuropathy. ${ }^{17}$ Secondly, choice of test: there is considerable evidence ${ }^{3}$ that conduction velocity of slower fibres (SFCV) is a more sensitive indicator of early lead neuropathy than maximum motor conduction velocity (MMCV). Thus MMCV measurements alone may be too insensitive to detect early lead neuropathy. Thirdly, variation in analysis of results: the most important difference between those studies in lead intoxication that indicate peripheral neuropathy and those that do not is the method of analysis. The former studies ${ }^{5-7}$ have compared a lead-exposed group and a control group, but in the latter ${ }^{8-11}$ results from leadexposed workers were compared with a normal range. The problem with this second method is that a normal range may extend over $20 \mathrm{~m} / \mathrm{s}^{12}$ due to factors such as experimental error, age, and interindividual variation. A man with high or moderate initial conduction velocity may suffer a small decrease and still remain within the normal range. This is particularly important if there is no correction for age and relatively young men are tested. Interestingly, the mean MMCV values of the nerves of lead workers tested by Seppalainen et $a l^{5} 7$ were all within the "normal" ranges ${ }^{12}$ even though they were statistically significantly lower than those of the control group.

In this study consideration of these factors led to a protocol that included examination of all commonly tested nerves, inclusion of an indicator of SFCV (percentage amplitude), and the use of a large sample with age-matched controls.

\section{Methods}

Ninety-four exposed men from a battery factory were tested. Their length of exposure varied from 6 months to 33 years ( 35 had been exposed for less than 10 years; 45 for 10 to 20 years, and 14 for more than 20 years). Because they worked in different areas of the factory exposure to lead ranged from light-for instance, automotive battery assembly - to heavy-for instance, lead mill, lead recovery, and pasting. Age-matched controls (matched to within one year with the lead workers) were taken from the administrative areas of the battery factory and from a nearby power station, and included both manual and office workers.

Analysis of blood and urine specimens and of measurements from neurophysiological recordings were performed on numbered samples so as to exclude observer bias. For nerve conduction velocity measurements room temperature ranged from $20^{\circ} \mathrm{C}$ to $26^{\circ} \mathrm{C}$ (average $23.7^{\circ} \mathrm{C}$ ). Minimum acceptable skin temperatures were: $31^{\circ} \mathrm{C}$ at the wrist, $33^{\circ} \mathrm{C}$ at the elbow, $30^{\circ} \mathrm{C}$ at the ankle, and $31^{\circ} \mathrm{C}$ at the knee. Preliminary experiments had shown that nerve conduction velocity was not significantly affected by normal skin temperature variations above these values. Skin temperature was measured with an Ellab electric universal thermometer (TE 3) with skin thermocouple.

All subjects completed a questionnaire ${ }^{13}$ designed to screen for neuropathy (symptoms, diseases, drug regimens, accidents, exposure to noxious substances other than lead, etc). This also confirmed that there were no symptoms of neuromuscular changes in the lead workers. Length of exposure to lead was also noted.

\section{Biochemical methods}

Blood and urine samples were taken after completion of neurophysiological tests for the day so that urine samples were not the first voided sample of the day, and all blood samples arrived in the laboratory less than one hour after collection, which is particularly important for $\delta$-aminolaevulinic acid dehydrase (ALA-D) determination. ${ }^{14}$

Blood lead estimations were carried out by the National Occupational Hygiene Service, Manchester, using the single tube monocolour dithizone technique described by Hoschek and Schittke. ${ }^{15}$ Erythrocyte ALA-D was measured by the method of Weissberg et al. ${ }^{14}$

Free erythrocyte protoporphyrin (FEP) was measured by the method of Rimington. ${ }^{16}$

Haemoglobin measurements were taken on a Coulter Model S fully automated cell counter from a $2.5 \mathrm{ml}$ sample of well-mixed blood. Urine lead was analysed using the dithizone method of Hoschek and Schittke ${ }^{15}$ by the National Occupational Hygiene Service, Manchester. Urine lead was corrected to a standardised osmolality of 1024 mOsm and in the corrected urine lead figures results with osmolality above $1030 \mathrm{mOsm}$ and below $1012 \mathrm{mOsm}$ were discarded. Both corrected and uncorrected results were used in the statistical analysis.

Urinary $\delta$-aminolaevulinic acid (ALA) was measured in the laboratories of Chloride Industrial Batteries, Clifton Junction, using the Bio-Rad ALA test. ${ }^{17}$ No correction was made for osmolality 
but samples below 1012 mOsm and above 1030 mOsm were discarded.

\section{Neurophysiological methods}

All measurements were made with a Medelec 2-channel electrophysiological recording system with PA407/15 pre-amplifiers, AA6 MKII amplifiers, DFO6 MKII display and fibreoptic unit, and Medelec NS6 stimulator delivering rectangular pulses of variable voltage, duration, and rate. Results were recorded from the fibreoptic unit in a light-proof box on to light-sensitive paper (Kodak Linagraph, 1895) and preserved with Kodak Linagraph stabilising lacquer.

Subjects were examined with their left arm abducted at $80^{\circ}$ on a padded board and the right leg supported by a small pillow under the thigh to assist relaxation. The left arm and right leg were tested in every case. Nerve length was measured with a tape measure (except for the radial nerve for which calipers were used). The distance from first cathode position of the stimulating electrodes, with the arm in the position of stimulation, was recorded. Three measurements were made for each nerve, and the mean of these was used to calculate the conduction velocity. All latency measurements were made from the traces several weeks after testing.

\section{MEASUREMENTS OF MMCV}

MMCV of the ulnar, median, radial, and peroneal nerves was measured by the method of Hodes et al..$^{18}$

The ulnar and median nerves were stimulated at the elbow and the wrist, and the muscle action potential was recorded from the abductor digiti minimi muscle and opponens pollicis muscle respectively. The radial nerve was stimulated at the axilla and mid-upper arm and the muscle action potential recorded from the brachioradialis. The peroneal nerve was stimulated at the knee and ankle, and the muscle action potential was recorded from the extensor digitorum brevis muscle.

Bipolar skin stimulation electrodes were used in all measurements of MMCV. Muscle action potentials were recorded using an active disc electrode over the belly of the recording muscle and a reference electrode over the tendon of the recording muscle. An earth electrode was strapped between the stimulating and recording electrodes. Recording electrodes were never touched between proximal and distal stimulations. Two traces were taken from each stimulation site. Voltage was always $30 \%$ supramaximal, as estimated by eye from the oscilloscope trace, before permanent records were taken. Stimuli of $0.1 \mathrm{~m} / \mathrm{s}$ to $0.5 \mathrm{~m} / \mathrm{s}$ duration and
100-300 V intensity were delivered at $1 \mathrm{~Hz}$. Gain and sweep speed were adjusted so that the largest possible complete action potential could be recorded.

Only identically shaped potentials at proximal and distal stimulation sites were accepted. The high and low frequency filters were set to $6 \mathrm{kHz}$ and $50 \mathrm{~Hz}$ respectively so that the signal included the range of the muscle action potentials but screened high and low frequency interference.

MEASUREMENT OF MAXIMUM SENSORY CONDUCTION VELOCITY (MSCV)

Ulnar maximum sensory nerve conduction velocity was measured from wrist to elbow by stimulating the fifth (little) finger with ring skin electrodes. The evoked nerve action potential was recorded at the wrist and the elbow along the path of the nerve, as determined during motor stimulation. A computer averager (AM6 CAT) was used for a minimum of 10 sweeps to help identify the nerve action potential. When necessary, additional sweeps were used. All MSCV measurements were averaged in this way as results from averaged and superimposed or single response measurements may differ. ${ }^{19}$ Stimuli of $0.1 \mathrm{~m} / \mathrm{s}$ duration and $100-300 \mathrm{~V}$ intensity were delivered at $2 \mathrm{~Hz}$. Bandwidth was set at $16 \mathrm{~Hz}$ to $3 \cdot 2 \mathrm{kHz}$. Voltage was $30 \%$ supramaximal.

MEASUREMENT OF SFCV

Gilliat $e t a l^{20}$ found that nerve damage in some subjects was indicated by a decrease in peroneal nerve action potential amplitude even though MMCV was normal. Poloni and $\mathrm{Sala}^{21}$ suggested that comparison of the temporal dispersions of proximally and distally produced muscle action potentials in ulnar and median nerves would give a method of measuring SFCV or, to be more precise, conduction velocity in fibres other than the fastest fibres. Amplitude will decrease proportionately with temporal dispersion. As amplitude can be measured more easily and accurately, comparison of amplitudes is used more often than temporal dispersion.

Comparison of the proximally and distally produced amplitudes is effected by expressing the amplitude of the proximally produced muscle action potential as a percentage of the amplitude of the distally produced muscle action potential. Mean ulnar MMCV was $53.4 \mathrm{~m} / \mathrm{s}$ in lead workers and $55.6 \mathrm{~m} / \mathrm{s}$ in control subjects $(\mathrm{p}<0.0005)$; mean median MMCV was $55.9 \mathrm{~m} / \mathrm{s}$ in lead workers and $57.3 \mathrm{~m} / \mathrm{s}$ in control subjects $(\mathrm{p}<0.01)$; mean radial MMCV was $63.9 \mathrm{~m} / \mathrm{s}$ in lead workers and $71.7 \mathrm{~m} / \mathrm{s}$ in control subjects $(\mathrm{p}<0.0005)$; mean peroneal MMCV was $46.1 \mathrm{~m} / \mathrm{s}$ in lead workers and $47.6 \mathrm{~m} / \mathrm{s}$ in control subjects $(\mathrm{p}<0.005)$. 
Table 1 Paired 1-tailed t-test: nerve measurements in lead workers and control subjects

\begin{tabular}{|c|c|c|c|c|c|c|c|c|c|}
\hline & \multirow[t]{2}{*}{ No } & \multicolumn{3}{|c|}{ Lead workers } & \multicolumn{3}{|c|}{ Controls } & \multirow[t]{2}{*}{$p$} & \multirow[t]{2}{*}{ Significance } \\
\hline & & Mean & $S D$ & Range & Mean & $S D$ & Range & & \\
\hline $\begin{array}{l}\text { Ulnar maximum motor } \\
\text { conduction velocity }(\mathrm{m} / \mathrm{s})\end{array}$ & 94 & $53 \cdot 4$ & $4 \cdot 1$ & $43-60$ & $55 \cdot 6$ & $4 \cdot 3$ & 49-68 & $<0.0005$ & Sig \\
\hline Median maximum motor & 94 & $55 \cdot 9$ & 3.9 & $41-65$ & $57 \cdot 3$ & 3.9 & $47-67$ & $<0.01$ & Sig \\
\hline $\begin{array}{l}\text { Radial maximum motor } \\
\text { conduction velocity }(\mathrm{m} / \mathrm{s})\end{array}$ & 91 & 63.9 & $12 \cdot 9$ & $40-87$ & $71 \cdot 7$ & $10 \cdot 1$ & 43-93 & $<0.0005$ & Sig \\
\hline $\begin{array}{l}\text { Peroneal maximum motor } \\
\text { conduction velocity }(\mathrm{m} / \mathrm{s})\end{array}$ & 91 & $46 \cdot 1$ & 3.7 & $31-53$ & $47 \cdot 6$ & $4 \cdot 0$ & 38-62 & $<0.005$ & Sig \\
\hline $\begin{array}{l}\text { Ulnar maximum sensory } \\
\text { conduction velocity }(\mathrm{m} / \mathrm{s})\end{array}$ & 76 & $57 \cdot 5$ & $4 \cdot 1$ & $46-65$ & $57 \cdot 9$ & 4.9 & $41-71$ & $>0.05$ & NS \\
\hline $\begin{array}{l}\text { Ulnar percentage } \\
\text { amplitude }\end{array}$ & 94 & $92 \cdot 2$ & $7 \cdot 4$ & $74-116$ & $92 \cdot 6$ & $9 \cdot 7$ & $62-123$ & $>0.05$ & NS \\
\hline $\begin{array}{l}\text { Median percentage } \\
\text { amplitude }\end{array}$ & 94 & $94 \cdot 2$ & $7 \cdot 3$ & $71-123$ & $94 \cdot 2$ & $9 \cdot 3$ & $64-120$ & $>0.05$ & NS \\
\hline $\begin{array}{l}\text { Peroneal percentage } \\
\text { amplitude }\end{array}$ & 91 & $86 \cdot 6$ & $10 \cdot 8$ & $66-111$ & $90 \cdot 3$ & $7 \cdot 9$ & 73-115 & $<0.005$ & Sig \\
\hline
\end{tabular}

\section{Results}

A group $t$-test comparing all the neurophysiological tests performed on the two groups of control workers (manual and office) showed no statistically significant differences between the two groups. The mean skin temperature of the control group was consistently lower (at all four test sites) than that of the lead-exposed subjects. The greatest difference between the means of each group was $0 \cdot 4^{\circ} \mathrm{C}$.

None of the 94 lead workers used for the final analysis had any symptoms of nerve damage or a history that would indicate the possibility of neuropathy arising from injury, disease, or exposure to noxious substances other than lead. The average blood lead at the time of testing was $2.9 \pm 0.7 \mu \mathrm{mol} / 1$ $(60 \pm 15 \mu \mathrm{g} / 100 \mathrm{ml})$.

The results of 1 -tailed paired $t$-tests comparing neurophysiological results of lead workers and controls are given in table 1. All MMCVs measured were statistically significantly decreased in the lead workers. Mean ulnar MMCV was $53.4 \mathrm{~m} / \mathrm{s}$ in lead workers and $55.6 \mathrm{~m} / \mathrm{s}$ in control subjects $(\mathrm{p}<0.0005)$; mean median MMCV was $55.9 \mathrm{~m} / \mathrm{s}$ in lead workers and $57.3 \mathrm{~m} / \mathrm{s}$ in control subjects $(\mathrm{p}<0.01)$; mean radial MMCV was $63.9 \mathrm{~m} / \mathrm{s}$ in lead workers and $71.7 \mathrm{~m} / \mathrm{s}$ in control subjects $(\mathrm{p}<0.0005)$; mean peroneal MMCV was $46.1 \mathrm{~m} / \mathrm{s}$ in lead workers and $47.6 \mathrm{~m} / \mathrm{s}$ in control subjects $(\mathrm{p}<0.005)$. MSCV was not significantly different between the lead workers and the controls. SFCV (as indicated by percentage amplitude) was significantly decreased in the peroneal nerve of lead workers but not in the median and ulnar nerves.

A Pearson correlation was carried out between each of the biochemical indices (blood lead, haemoglobin, ALA-D, free erythrocyte protoporphyrin, urine lead, corrected urine lead, urinary
ALA) and each of the neurophysiological measurements. The only statistically significant correlation $(p<0.05)$ was a positive correlation between blood lead and ulnar MMCV (table 2) indicating, unexpectedly, a faster nerve conduction velocity with higher blood leads.

The possibility that biochemical changes decreased with increasing age because men were moved to lighter-that is, less lead-exposed-jobs was tested using a Pearson correlation, as such an association might have obscured any relationship between biochemical and neurophysiological parameters. There was, however, no significant correlation between any of the biochemical measurements and age.

As both conduction velocity and length of exposure are associated with age, multiple regression analysis was carried out to determine the contribution of length of exposure in predicting conduction velocity in lead workers (table 3). Those results indicate that length of exposure to lead contributes significantly $(p<0.05)$ in the prediction of ulnar

Table 2 Pearson correlation analysis: ulnar maximum motor conduction velocity and biochemical measurements in lead workers

\begin{tabular}{|c|c|c|c|c|c|}
\hline $\begin{array}{l}\text { Ulnar maximum motor } \\
\text { conduction velocity } \\
\text { correlated with: }\end{array}$ & No & $\boldsymbol{r}$ & Slope & $p$ & $\begin{array}{l}\text { Significance } \\
(\text { at } 95 \% \\
\text { level) }\end{array}$ \\
\hline $\begin{array}{l}\text { Blood lead } \\
\text { 8-Aminolaevulinic acid } \\
\text { dehydrase }\end{array}$ & $\begin{array}{l}91 \\
94\end{array}$ & $\begin{array}{l}0.246 \\
0.075\end{array}$ & $\begin{array}{l}0.072 \\
0.076\end{array}$ & $\begin{array}{l}0.019 \\
0.471\end{array}$ & $\begin{array}{l}\text { Sig } \\
\text { NS }\end{array}$ \\
\hline $\begin{array}{l}\text { Free erythrocyte } \\
\text { protoporphyrin }\end{array}$ & 91 & 0.192 & 0.014 & 0.070 & NS \\
\hline $\begin{array}{l}\text { Haemoglobin } \\
\text { Urinary } \delta \text {-aminolaevulinic } \\
\text { acid }\end{array}$ & $\begin{array}{l}94 \\
72\end{array}$ & $\begin{array}{r}-0.085 \\
0.056\end{array}$ & $\begin{array}{r}-0.416 \\
0.034\end{array}$ & $\begin{array}{l}0.415 \\
0.639\end{array}$ & $\begin{array}{l}\text { NS } \\
\text { NS }\end{array}$ \\
\hline $\begin{array}{l}\text { Urine lead } \\
\text { Corrected urine lead }\end{array}$ & $\begin{array}{l}92 \\
86\end{array}$ & $\begin{array}{l}0 \cdot 203 \\
0 \cdot 146\end{array}$ & $\begin{array}{l}0.178 \\
0.090\end{array}$ & $\begin{array}{l}0.053 \\
0.181\end{array}$ & $\begin{array}{l}\text { NS } \\
\text { NS }\end{array}$ \\
\hline
\end{tabular}


Table 3 Multiple regression analysis to show the contribution of length of exposure in determining conduction velocity of lead workers

\begin{tabular}{|c|c|c|c|c|c|c|c|c|c|}
\hline \multirow[t]{2}{*}{ Dependent variable } & \multicolumn{3}{|l|}{ Age } & \multicolumn{3}{|c|}{ Length of exposure } & \multicolumn{3}{|c|}{ Overall } \\
\hline & $F$ & $p$ & Sig & $F$ & $p$ & Sig & $F$ & $p$ & Sig \\
\hline $\begin{array}{l}\text { Ulnar maximum motor } \\
\text { conduction velocity }\end{array}$ & $0 \cdot 168$ & $>0.05$ & NS & $4 \cdot 033$ & $<0.05$ & Sig & 6.016 & $<0.005$ & Sig \\
\hline $\begin{array}{l}\text { Median maximum motor } \\
\text { conduction velocity }\end{array}$ & $1 \cdot 160$ & $>0.05$ & NS & $0 \cdot 414$ & $>0.05$ & NS & 6.094 & $<0.005$ & Sig \\
\hline $\begin{array}{l}\text { Radial maximum motor } \\
\text { conduction velocity }\end{array}$ & $1 \cdot 324$ & $>0.05$ & NS & $2 \cdot 867$ & $>0.05$ & NS & 1.681 & $>0.05$ & NS \\
\hline $\begin{array}{l}\text { Peroneal maximum motor } \\
\text { conduction velocity }\end{array}$ & 0.401 & $>0.05$ & NS & 0.058 & $>0.05$ & NS & 1.586 & $>0.05$ & NS \\
\hline $\begin{array}{l}\text { Peroneal percentage } \\
\text { amplitude }\end{array}$ & 0.483 & $>0.05$ & NS & $0 \cdot 122$ & $>0.05$ & NS & 0.077 & $>0.05$ & NS \\
\hline
\end{tabular}

Sig $=$ Significance.

MMCV; increased length of exposure being associated with decreased MMCV. Length of exposure, however, made no significant contribution to prediction of the other conduction velocities affected by lead.

One-tailed paired $t$-tests were carried out to determine the minimum length of exposure that would produce statistically significant reduction in nerve conduction velocity in lead workers. Thirteen men had been exposed to lead for less than two years, of whom five had been exposed for less than one year. There was no significant reduction in conduction velocity in the five men exposed to lead for one year or less. Significant decreases in ulnar, radial, and peroneal MMCV, and peroneal percentage amplitude, however, were observed in the 13 men exposed to lead for two years or less (table 4). In this group of men blood lead concentration had not risen above $3.9 \mu \mathrm{mol} / 1(80 \mu \mathrm{g} / 100 \mathrm{ml})$ in their three-monthly tests. The blood lead of one of these subjects was $3.9 \mu \mathrm{mol} / \mathrm{l}(80 \mu \mathrm{g} / 100 \mathrm{ml})$ at the time of testing but on retesting one week later it was below that level. The mean blood lead concentration at the time of testing was $2 \cdot 8 \pm 0 \cdot 8 \mu \mathrm{mol} / 1(58 \pm 16$ $\mu \mathrm{g} / 100 \mathrm{ml})$. It appears therefore that nerve damage can occur within two years of initial exposure to lead and at blood lead levels of less than $3.9 \mu \mathrm{mol} / \mathrm{l}$ $(80 \mu \mathrm{g} / 100 \mathrm{ml})$.

\section{Discussion}

The absence of significant differences in conduction velocity in the group $t$-test comparing manual and office workers in the control group, indicates that the use of office staff in the control group did not affect the overall results.

The difference in mean skin temperature between lead workers and controls never exceeded $0 \cdot 4^{\circ} \mathrm{C}$, the latter having consistenly lower mean skin temperatures at all stimulation sites. Possibly this consistent difference introduces a small error. As the effect of cooling would be to decrease mean conduction velocities, ${ }^{22-24}$ however, the lower conduction velocities of the lead workers cannot be attributed to the effects of temperature.

It is apparent from this study that nerve changes occur in men exposed to lead even in the absence of symptoms of neurological disturbance. This is in general agreement with the findings of other workers, ${ }^{3} 57$ though there are some differences in the present study. MMCV was statistically significantly lower in lead-exposed men compared with their age-

Table 4 Paired 1-tailed t-test on lead workers exposed to lead for two years or less and age-matched controls $(n=13)$

\begin{tabular}{|c|c|c|c|c|}
\hline Measurement & $\begin{array}{l}\text { Lead workers } \\
\text { Mean } \pm S D\end{array}$ & $\begin{array}{l}\text { Controls } \\
\text { Mean } \pm S D\end{array}$ & $p$ & Significance \\
\hline $\begin{array}{l}\text { Age }(\mathrm{yr}) \\
\text { Blood lead concentration }(\mu \mathrm{g} / 100 \mathrm{ml}) \\
\text { Length of exposure to lead }(\mathrm{yr}) \\
\text { Ulnar maximum motor conduction velocity }(\mathrm{m} / \mathrm{s}) \\
\text { Median maximum motor conduction velocity }(\mathrm{m} / \mathrm{s}) \\
\text { Radial maximum motor conduction velocity }(\mathrm{m} / \mathrm{s}) \\
\text { Peroneal maximum motor conduction velocity }(\mathrm{m} / \mathrm{s}) \\
\text { Peroneal percentage amplitude }\end{array}$ & $\begin{array}{l}26 \pm 4 \\
58 \pm 16 \\
1 \cdot 5 \pm 0 \cdot 59 \\
55 \cdot 1 \pm 3 \cdot 0 \\
58 \cdot 4 \pm 3 \cdot 5 \\
58 \cdot 1 \pm 13 \cdot 5 \\
46 \cdot 6 \pm 1 \cdot 9 \\
86 \cdot 4 \pm 7 \cdot 0\end{array}$ & $\begin{aligned} & 26 \pm 4 \\
& 24 \pm 14 \\
& 0 \\
& 58 \cdot 0 \pm 4 \cdot 5 \\
& 59 \cdot 8 \pm 4 \cdot 2 \\
& 74 \cdot 1 \pm 10 \cdot 4 \\
& 49 \cdot 9 \pm 4 \cdot 8 \\
& 91 \cdot 8 \pm 6 \cdot 3\end{aligned}$ & $\begin{array}{l}<0.0005 \\
= \\
<0.05 \\
>0.05 \\
<0.005 \\
<0.05 \\
<0.05\end{array}$ & $\begin{array}{l}\overline{\text { Sig }} \\
\text { Sig } \\
\text { NS } \\
\text { Sig } \\
\text { Sig } \\
\text { Sig }\end{array}$ \\
\hline
\end{tabular}


matched controls in all motor nerves tested (median, ulnar, radial, and peroneal). Seppalainen et $a l^{7}$ did not find a significant reduction in MMCV of the peroneal nerve, though significant changes were found in median and ulnar nerves of 25 lead workers. They did not test the radial nerve. Catton et al ${ }^{3}$ tested only the peroneal nerve and found no reduction in MMCV of 19 lead workers, although there was a significant reduction in peroneal percentage amplitude. Seppalainen and Hernberg 5 found significantly reduced MMCV in median, ulnar, and peroneal nerves of 35 lead-exposed workers, though again the radial nerve was not tested. The absence of change in the MMCV of the peroneal nerve in the studies of Catton et $\mathbf{l}^{3}$ and Seppalainen and Hernberg ${ }^{5}$ may be attributable to the small number of men tested. In the present study a difference of only $1.5 \mathrm{~m} / \mathrm{s}$ was observed between the mean values of control and lead-exposed subjects (standard deviations were $4.0 \mathrm{~m} / \mathrm{s}$ and $3.7 \mathrm{~m} / \mathrm{s}$ respectively). With a large variation relative to the observed difference, statistically significant differences would not be expected with a relatively small number of subjects.

No change was found in ulnar MSCV in this study, confirming both the general clinical observation that sensory neuropathy is rare in lead poisoning and the finding of Seppalainen et $^{\mathrm{al}} \mathrm{l}^{7}$ that maximum sensory conduction velocity was not significantly affected in either median or ulnar nerves of symptomless lead workers.

Reduction of peroneal percentage amplitude was observed in lead workers compared with their controls, confirming an earlier report of reduced peroneal percentage amplitude in lead workers with no neurological symptoms. ${ }^{3}$

No changes were observed in median and ulnar percentage amplitudes in lead workers in this study. This is in contradiction to the findings of Seppalainen et $a l^{5} 7$ who found that SFCV of the ulnar nerve measured by the antidromic blocking technique was one of the most sensitive indicators of early lead neuropathy. Probably the failure to find changes in ulnar and median SFCV in this study arises from the inappropriateness of the technique used (percentage amplitude) rather than an absence of change in the slower fibres of these nerves. Some cross-stimulation may occur in the median and ulnar nerves, that is submaximal stimulation of the ulnar nerve during testing of the median nerve due to spread of current when using the high voltages necessary with skin stimulation electrodes. This could obscure changes in amplitude.

Only one of the Pearson correlations between biochemical and neurophysiological measurements was statistically significant. The unexpected positive correlation between blood lead and ulnar MMCV (table 2) is not compatible with the basic observation of this study and of Seppalainen et $a l^{5}$ that MMCV is lower in lead-exposed subjects than in controls. There was a possibility that the effect of age was interfering with the relationship between biochemical and nerve change because conduction velocity decreases with increasing age. ${ }^{1925-28}$ In the survey factory older men tend to be removed from jobs with very heavy exposure to lead so that with increasing age biochemical measurements move closer to normal values. For these reasons decreased conduction velocity might appear to be associated with, for example, decreased blood lead concentrations. There was no significant correlation, however, between age and any of the biochemical measurements (table 3). Possibly some interaction with age has occurred or some other unconsidered variable has produced this anomalous result. Alternatively, this result may be due to chance (rejecting the null hypothesis of no association when it is true) as at the $5 \%$ significance level this size of correlation coefficient will occur by chance one in 20 times, and altogether 35 correlations were performed.

The lack of correlation between nerve changes and biochemical indices in lead workers observed in this survey has been noted many times before. ${ }^{2-5} 729$ There are some reports, however, of a relationship between biochemical and neurophysiological changes during exposure to lead. Thus Sessa et al ${ }^{1}$ observed that decreased ulnar MMCV was paralleled by increased free erythrocyte protoporphyrins and Catton et $a l^{3}$ noted an association between nerve changes and anaemia, though this was not tested statistically. In the present study there is no evidence of a relationship between nerve change and either free erythrocyte protoporphyrin levels or haemoglobin concentrations.

The correlation between ulnar MMCV and length of exposure to lead supports the finding of Lane and Lewy, ${ }^{29}$ who noted that the greater the length of exposure to lead the greater were the neurophysiological changes (in chronaxie and rheobase). The fact, however, that this association was found only in one of the affected nerves in the present study (table 3 ) indicates that although length of exposure may be one of the factors determining the degree of nerve damage, there are other factors.

Possibly inter-individual variation in nerve conduction velocity of men, which has been calculated to be up to $4.5 \mathrm{~m} / \mathrm{s}^{30}$ (standard error of the estimate from a regression line of the median nerve MMCV on age) is so great that any relationship between the relatively small lead-induced changes (table 1 ) and, for example, the degree or length of exposure to lead is obscured. Alternatively, individual susceptibility 
could be the predominant factor in determining the effect of lead on nerves. This variation in individual susceptibility has been observed clinically many times, in that the same blood lead concentration may be associated with pronounced signs and symptoms in one patient and no observed illeffect in another. In animal experiments Fullerton ${ }^{31}$ also observed that the degree of nerve damage produced by equal doses of lead varied greatly in different guinea pigs, apparently indicating variation in individual susceptibility.

Having established that a subclinical neuropathy was present in the lead workers tested, it seemed possible that this was a residual neuropathy due to high levels of exposure to lead in days before stringent medical testing. More than half of the test population ( $59 \mathrm{men}$ ) had been exposed to lead for more than 10 years-that is, before determination of lead in blood in the factory was initiated in 1964. Lane and Lewy ${ }^{29}$ suggested that nerve damage produced by very long exposure to high levels of lead may never be repaired.

The small substudy carried out on lead workers exposed for two years and less is interesting because those men had been tested every three months since starting work at the factory, and their lead in blood had never risen above $3.9 \mu \mathrm{mol} / 1(80 \mu \mathrm{g} / 100 \mathrm{ml})$. It is clear from table 4 that even at blood lead concentrations below $3.9 \mu \mathrm{mol} / 1(80 \mu \mathrm{g} / 100 \mathrm{ml})$ nerve changes occur. The mean blood lead of the 13 men at the time of testing was $2 \cdot 8 \pm 0 \cdot 8 \mu \mathrm{mol} / 1$ $(58 \pm 16 \mu \mathrm{g} / 100 \mathrm{ml})$, so although residual neuropathy may explain the overall results, this substudy indicates that nerve changes occur at blood lead concentrations of less than $3.9 \mu \mathrm{mol} / 1(80 \mu \mathrm{g} / 100 \mathrm{ml})$ and also that the onset of neurophysiological changes follows relatively rapidly after exposure to lead.

This study did not clarify the site of action of lead in the nervous system except to confirm that there is lower motor neurone involvement. The possibility of upper motor neurone ${ }^{11}$ or muscle ${ }^{32} 33$ involvement has not been excluded, and the possibility of a multifactorial aetiology of lead neuropathy remains. The action of lead on the lower motor neurone is not clear. Despite the observation that considerably reduced conduction velocity in guinea pigs is associated with segmental demyelination and not with axonal degeneration ${ }^{31}$ the fact that decreased conduction velocity is found in this study does not preclude axonal degeneration. Theoretically, axonal degeneration could spread sufficiently to produce decreased conduction velocity in chronic lead exposure as opposed to the acute animal experiments of Fullerton. ${ }^{31}$ Histological evidence points to axonal degeneration as the major effect of lead on the lower motor neurone in man. ${ }^{34-36}$
The occurrence in the past of wrist drop as the most common neurological manifestation of lead poisoning has tended to suggest that the radial nerve is affected more than other motor nerves. It is difficult to understand on what basis there could be a differential effect, though one possibility is that the initial change is a functional rather than structural one, as postulated by Norris $e^{2} a^{\mathbf{b}^{37}}$ as the basis for the decrease in conduction velocity in old age. Alternatively, perhaps the wrist extensors served by the radial nerve may be good indicators of what is in fact a generalised motor neuropathy as they are relatively small, weak muscles but often used.

It is not clear from the findings of this study if there is a selective action of lead on particular motor nerves. Straightforward comparison between the nerves is not valid because the co-efficient of variation will vary between nerves particularly as different techniques-for example, caliper and tape measurements-were used for different nerves.

I thank Professor W R Lee for his supervision and advice; the European Economic Commission and Chloride Industrial Batteries Ltd for financial support for this investigation; Mrs S Hall and Miss A Kirsten for technical help; Dr J Taylor and all the medical staff at CIB Ltd, Clifton Junction; and the management and trades unions at CIB Ltd, Clifton Junction, and the Central Electricity Generating Board, Kearsley, for their co-operation. Above all I must thank those men who volunteered for tests and cheerfully co-operated in them. I would also like to thank $\mathrm{Mr} \mathrm{C} \mathrm{J}$ Whitaker for help in preparing this paper.

This work formed part of a thesis submitted to the University of Manchester for the degree of MSc by J A S Ashby (formerly Archibald).

\section{References}

${ }^{1}$ Sessa T, Ferrari E, Colucci d'Amato C. Nerve conduction velocity in patients with lead poisoning. Folia Med $1965 ; 48: 658-68$.

${ }^{2}$ Bergamini V, Sibour F. Early diagnosis of affections of the peripheral nervous system caused by exogenous poisoning. Neurophysiological studies. Riv Patol Nerv Ment 1960;81:415-39.

${ }^{3}$ Catton MJ, Harrison MJG, Fullerton PM, Kazantzis G. Subclinical neuropathy in lead workers. $\mathrm{Br} \mathrm{Med} J$ 1970;ii :80-2.

${ }^{4}$ Mostafa M, El-Sewef AZ, Talat Abdel Hamid. Clinical, biochemical, and electromyographic study in Egyptian lead workers. Med Lav 1972;63:109-16.

${ }^{5}$ Seppalainen AM, Hernberg S. Sensitive technique for detecting subclinical lead neuropathy. Br J Ind Med 1972; 29:443-9.

6 Vasilescu C. Motor nerve conduction velocity and electromyogram in chronic lead poisoning. Rev Roum Neurol 1973;10:221-6. 
' Seppalainen AM, Tola S, Hernberg S, Kock B. Subclinical neuropathy at "safe" levels of lead exposure. Arch Environ Health 1975;30:180-3.

${ }^{8}$ Simpson JA, Seaton DA, Adams JF. Response to treatment with chelating agents of anaemia, chronic encephalopathy and myelopathy due to lead poisoning. $J$ Neurol Neurosurg Psychiatry 1964;27:536-41.

- Delwaide PJ, Chantraine JM. Participation spinale dans l'intoxication saturnine: arguments electromyographiques. In: Proceedings of the Sixth International Congress on Electroencephalography and Clinical Neurophysiology, Vienna. Amsterdam: Elsevier, 1965: 643-6.

10 Preiskel P. Chronic lead poisoning: myopathy or neuritis? Ann Phys Med 1958;4:293-6.

1 Boothby JA, De Jesus PV, Rowland LP. Reversible forms of motor neuron disease. Arch Neurol 1974;31:18-23.

12 Smorto MP, Basmajian JV. Clinical electroneurography: an introduction to nerve conduction tests. Baltimore: Williams and Wilkins, 1972.

13 Archibald JAS. A clinical and biochemical study of early lead poisoning. University of Manchester, 1976. (MSc thesis in the faculty of medicine.)

14 Weissberg JB, Lipschutz F, Oski FA. $\delta$-aminolevulinic acid dehydratase activity in circulating blood cells. A sensitive laboratory test for the detection of childhood lead poisoning. $N$ Engl J Med 1971;284:565-9.

15 Hoschek R, Schittke HJ. Interlaboratory comparison of measurements for lead in blood, in urine and cadmium in urine. Zentbl Arbeitsmed 1973;23:243-8.

${ }^{16}$ Rimington C. Quantitative determination of porphobilinogen and porphyrins in urine and porphyrins in faeces and erythrocytes. London: Association of Clinical Pathologists, 1971 :broadsheet 70.

${ }^{17}$ Davis JR, Andelman SL. Urinary delta-aminolevulinic acid (ALA) levels in lead poisoning. IA modified method for the rapid determination of urinary delta-aminolevulinic acid using disposable ion-exchange chromatography columns. Arch Environ Health 1967;15:53-9.

${ }^{18}$ Hodes R, Larrabee MG, German W. The human electromyogram in response to nerve stimulation and the conduction velocity of motor axons; studies on normal and on injured peripheral nerves. Arch Neurol Psychiat $1948 ; 60: 340-65$.

19 Sato K. Nerve conduction studies in man. Electromyography 1967;7:175-6.

${ }^{20}$ Gilliat RW, Goodman HV, Willison RG. The recording of lateral popliteal nerve action potentials in man. $J$ Neurol Neurosurg Psychiatry 1961;24:305-18.

21 Poloni AE, Sala E. The conduction velocity of the ulnar and median nerves stimulated through a twin needle electrode. In : Pinelli P, ed. Progress in electromyography.
Amsterdam: Elsevier, 1962. (Suppl 22, EEG clin neurophysiol 17.)

${ }^{22} \mathrm{~K}$ ato $\mathrm{M}$. The conduction velocity of the ulnar nerve and the spinal reflex time, measured by means of the $\mathrm{H}$ wave in average adults and athletes. Tohoku J Exp Med 1960; 73:74-85.

${ }^{23}$ Henrikson JD. Conduction velocity of motor nerves in normal subjects and patients with neuromuscular disorders. University of Minnesota, 1956. (Master of science thesis in physical medicine and rehabilitation, graduate school.)

${ }^{24}$ Gassel MM, Trojaborg W. Clinical and electrophysiological study of the pattern of conduction times in the distribution of the sciatic nerve. $J$ Neurol Neurosurg Psychiatry 1964;27:351-7.

${ }^{25}$ Wagman IH, Lesse $\mathrm{H}$. Maximum conduction velocities of motor fibres of ulnar nerve in human subjects of various ages and sizes. $J$ Neurophysiol $1952 ; 15: 235-44$.

${ }^{26}$ Miglietta $\mathrm{O}$, Lowenthal $\mathrm{M}$. Nerve conduction velocity and refractory period in peripheral vascular diseases. $J$ Appl Physiol 1962;17:837-40.

${ }^{27}$ Lafratta CM, Smith OH. A study of the relationship of motor nerve conduction velocity in the adult to age, sex and handedness. Arch Phys Med Rehabil 1964;45: 407-12.

${ }^{28}$ Lucci RM. The effects of age on motor nerve conduction velocity. Phys Ther 1969;49:473-6.

${ }^{29}$ Lane R, Lewy FH. Blood and chronaximetric examination of lead workers subjected to different degrees of exposure. A comparative study. J Industr Hyg 1935;17:79-92.

${ }^{30}$ Nielson VK. Sensory and motor nerve conduction in the median nerve in normal subjects. Acta Med Scand $1973 ; 194: 435-43$.

${ }^{31}$ Fullerton PM. Chronic peripheral neuropathy produced by lead poisoning in guinea pigs. $J$ Neuropathol Exp Neurol 1966;25:214-36.

${ }^{32}$ Brain WR. Diseases of the nervous system. 7th ed. London: Oxford University Press, 1969.

${ }^{33}$ Fazlullah S, Ramamurthi B. Lead intoxication and the nervous system. J Indian Mea Assoc 1965;44:644-8.

${ }^{34}$ Herter CA. Report of a case of lead paralysis with special reference to cytological changes in the nervous system and the distribution of lead. NY Med J 1895;61:665-7.

${ }^{35}$ Behse F, Pach J, Dorndorf W. Polyneuropathy due to lead poisoning. Clinical electrophysiological and biopsy findings. $Z$ Neurol 1972;202:209-16.

${ }^{36}$ Laslett EE, Warrington WB. The morbid anatomy of a case of lead paralysis: condition of the nerves, muscles, muscle spindles, and spinal cord. Brain 1898;21:224-31.

${ }^{37}$ Norris AW, Shock NW, Wagman IM. Age changes in the maximum conduction velocity of motor fibres of human ulnar nerves. J Appl Physiol 1953;5:589-93. 